SCientiæ studia, São Paulo, v. 13, n. 2, p. 335-67, 2015

\title{
त्री \\ Uma certa latitude: Georges Canguilhem, biopolítica e vida como errância
}

\author{
Vladimir SAFAtLE
}

\begin{abstract}
范
RESUMO

Este artigo procura discutir a possibilidade de uma biopolítica que não seja apenas a descrição dos mecanismos disciplinares de administração dos corpos e de gestão calculista da vida, mas possa fornecer um fundamento para a crítica social do capitalismo contemporâneo. Para tanto, trata-se de derivá-la do vitalismo de Georges Canguilhem e de suas discussões a respeito da normatividade vital, das relações entre o normal e o patológico e da errância própria à atividade vital. Ao fim desse processo, veremos como a processualidade interna ao conceito de vida poderá aparecer como fator determinante para a reorientação do pensamento crítico e de uma teoria sobre o conceito de norma.
\end{abstract}

Palavras-chave • Biopolítica. Errância. Vida. Normatividade. Patologia. Normalidade. Contingência.

“A saúde é precisamente, e principalmente
no homem, uma certa latitude (...).”
Georges Canguilhem (2003, p.214).

"Nós vivemos no esquecimento de nossas metamorfoses." Paul Éluard (1946, p. 83).

Este artigo visa discutir certas modalidades possíveis de relação entre a biologia e a política. Ele parte de uma crítica às noções hegemônicas de biopolítica, em especial àquelas derivadas do trabalho de Michel Foucault. A noção de Foucault tem como uma de suas características fundamentais ser eminentemente crítica, ou seja, ela visa denunciar a maneira pela qual os mecanismos disciplinares constituem o que é biológico enquanto campo naturalizado de normatividades e valores que expressarão processos sociais de gestão da vida e dos corpos. No entanto, tal noção parte do pressuposto da ausência de autonomia ontológica da vida e da natureza, o que impede que tais conceitos possam fornecer uma base normativa para o desenvolvimento da crítica. Se estivermos atentos à reflexão de Georges Canguilhem, principalmente no que se refere a 
problemas tais como a distinção saúde/doença, a errância própria à normatividade vital, a função da contingência na reconfiguração de formas orgânicas, poderemos recuperar seu vitalismo e utilizá-lo como horizonte de uma biopolítica que será, também, fundamento normativo para a crítica social. Isto é o que espero fazer no decorrer deste artigo. Mas, para tanto, convém iniciar discutindo certas limitações do conceito foucaultiano de biopolítica.

\section{VIDA E POLÍTICA}

"É a vida, muito mais que o direito, que se transformou no objeto de embate das lutas políticas, mesmo que estas se formulem através da afirmação de direitos" (Foucault, 1976, p. 191). A frase de Michel Foucault evidencia a cristalização de uma importante mutação na compreensão das estruturas de poder operada nas últimas décadas. Ela expressa a consciência de como as discussões a respeito dos mecanismos de "administração dos corpos e de gestão calculista da vida” (p. 187) passaram a ocupar o cerne dos embates em torno dos efeitos da sujeição social. Mecanismos que mostravam como o fundamento da dimensão coercitiva do poder encontrava-se em sua capacidade de produzir horizontes disciplinares de formas de vida. Assim, desde que Foucault usou sistematicamente termos como "biopoder" e "biopolítica", ficamos ainda mais sensíveis à maneira pela qual os discursos disciplinares sobre a sexualidade, as disposições corporais, a saúde e a doença, a experiência do envelhecimento e do autocontrole estabelecem as normatividades que produzem a ideia social de uma vida possível de ser vivida. Daí uma afirmação maior como:

Durante milênios, o homem permaneceu aquilo que ele era para Aristóteles, um animal vivente que, além disso, era capaz de uma existência política. $\mathrm{O}$ homem moderno é um animal na política do qual sua vida de ser vivente é uma questão (Foucault, 1976, p. 188).

No entanto, dizer que a vida se transformou no objeto de embate das lutas políticas é ainda, ao menos na perspectiva foucaultiana, dizer um pouco mais. Pois, em seu caso, trata-se de afirmar que o biológico não poderia ser visto como um campo autônomo de produção de normatividades capazes de alguma forma de determinação de nossos possíveis sociais. Ele não deveria sequer ser um ponto de imbricação entre vida

I "Biopolítica" é um termo cunhado provavelmente por Rudolph Kjellén, em 1920, para descrever sua concepção do estado como uma "forma vivente" (Lebenform) provida da organicidade própria a uma forma biológica (cf. Kjellén, 1920, p. 3-4). Para uma genealogia do conceito de biopolítica, cf. Esposito, 2008. 
e história, pois quem diz "imbricação" pressupõe dois polos que podem se distinguir ontologicamente . Notemos, por exemplo, o sentido de uma afirmação como a de Michel Foucault a respeito da noção de biopoder.

Conjunto de mecanismos através dos quais o que, na espécie humana, constitui seus traços biológicos fundamentais poderá entrar no interior de uma política, de uma estratégia política, de uma estratégia geral do poder; dito de outra forma, como a sociedade, as sociedades ocidentais modernas, a partir do século xviıI, levaram em conta o fato biológico fundamental de que o ser humano constitui uma espécie humana (Foucault, 2004, p. 3).

Ao fazer tal afirmação, Foucault afirma que os traços biológicos fundamentais da espécie humana podem entrar no interior de uma estratégia política, não porque a política está determinada, limitada por tais fundamentos biológicos, ou procura imitálos, mas porque o biológico, ao menos no interior de uma problemática política, deve aparecer necessariamente como aquilo que não tem fundamento que lhe seja próprio. ${ }^{2}$ Haveria uma plasticidade que lhe seria constitutiva, que permitiria ao biológico ser algo como uma história esquecida de sua própria natureza. Não por outra razão, já em As palavras e as coisas, as reflexões sobre o biológico são apresentadas estritamente como a exposição da vida enquanto expressão de epistemes historicamente determinadas. O que permite Foucault afirmar que, se a biologia era desconhecida no século xvıı,, "havia uma razão bastante simples para isso: é que a vida enquanto tal não existia. Havia apenas seres vivos e que apareciam através de uma grelha de saber constituído pela história natural" (Foucault, 1966, p. 139). Dessa forma, a vida nunca aparecerá para Foucault como o que força discursos em direção a transformações estruturais. Como consequência, será difícil não chegar a um fenômeno bem descrito por Giorgio Agamben:

É como se, a partir de um certo ponto, todo evento político decisivo tivesse sempre uma dupla face: os espaços, as liberdades e os direitos que os indivíduos ad-

\footnotetext{
2 Isto talvez explique, como perceberam alguns comentadores, porque o conceito de vida, em Foucault, nunca é explicitamente determinado, "permanecendo essencialmente implícito" (Muhle, 2008, p. 10). Ele só pode permanecer implícito por ser, ao menos para Foucault, um conceito sem autonomia ontológica. Muhle defende outra hipótese, a saber, que há um "duplo papel da vida" em Foucault: como objeto de uma biopolítica e como modelo funcional a ser imitado pela biopolítica. No entanto, é preciso insistir que a vida nunca é pensada por Foucault a partir de uma organização conceitual imanente, como vemos em Canguilhem (com os conceitos de errância, de normatividade vital, de organismo, de relação ao meio ambiente, entre outros). Por isso, a meu ver, pode-se dizer que, no máximo, há uma latência no pensamento de Foucault para, em certas situações, permitir que a vida apareça como modelo funcional a ser imitado. Mas uma latência é algo muito diferente de uma tarefa filosófica assumida.
} 
quirem no seu conflito com os poderes centrais simultaneamente preparam, a cada vez, uma tácita, porém crescente, inscrição de suas vidas na ordem estatal, oferecendo assim uma nova e mais temível instância (Agamben, 2002, p. 127).

Esse esvaziamento ontológico da vida no interior das reflexões sobre as estratégias políticas faz com que todo reconhecimento de uma dimensão vital no interior do campo político seja compreendida como crescente codificação na ordem estatal, como contínua modelagem da vida pelo poder. Isso abre as portas, ao menos no interior da leitura proposta por Agamben, para toda biopolítica possível tornar-se indiscernível das formas de gestão próprias a um poder soberano que opera através da completa despossessão dos sujeitos. Poder capaz de transformar espaços sociais em zonas de gestão da anomia. A biopolítica, nesta leitura, não pode ser outra coisa que uma técnica do poder soberano, pois descreve o impacto do poder soberano na constituição de uma vida sem predicados, de uma vida completamente desnudada de sua normatividade imanente.

Talvez a aposta em tal esvaziamento ontológico da vida possa ser justificada, se lembrarmos o que foi, até bem pouco tempo, o uso político do biológico. Não se trata apenas de lembrar dos usos do biológico como horizonte de justificação de políticas eugenistas e racistas (Rudolph Hess afirmava, por exemplo: "o nacional-socialismo nada mais é que biologia aplicada") ou da brutalidade da espoliação econômica a partir do darwinismo social. Lembremos de como a articulação entre a biologia e a política sempre teve em vista a defesa da "corporeidade do social", da organização "natural" do social como um corpo unitário que expressaria a crença na simplicidade funcional das organizações vitais, crença que forneceria uma visão fortemente funcionalista e hierarquizada da estrutura social e que nos levaria a compreender, entre outras coisas, conflitos sociais como expressões tendenciais de patologias que devem ser extirpadas, como se retira um tecido em necrose. Já em Hobbes, os antagonismos e conflitos sociais eram descritos como patologias cuja gramática derivava-se das nosografias das doenças de um organismo biológico. ${ }^{3}$ A política só pode aparecer aqui como imunização contra o adoecimento do corpo social.

Quando, séculos mais tarde, a sociologia de Émile Durkheim descrever as desregulações da normatividade como situações de "patologias sociais" (Durkheim, 1988), encontraremos a permanência de uma perspectiva que se serve do biológico para legitimar que a vida social obedeça a dinâmicas previamente estabelecidas. Pois o paralelismo assumido entre indivíduo e sociedade através do uso sociológico de um voca-

3 Basta lembrarmos aqui dos paralelismos presentes no capítulo 29 do Leviatã, no qual Hobbes descreve "as enfermidades de um Estado" a fim de nos alertar para "aquelas coisas que enfraquecem ou tendem à dissolução da república" (cf. Hobbes, 2002). 
bulário médico permite a Durkheim falar da sociedade como de um "organismo" ou de um "corpo" que precisa de intervenções a fim de livrar-se de acontecimentos que a enfraquecem e a fazem adoecer. Tais analogias serão fundamentais para as primeiras discussões sobre a biopolítica, ainda no período anterior à Segunda Guerra (cf. Roberts, 1938; Uexküll, 1920). O termo foi, de fato, criado para inicialmente forçar a analogia entre o biológico e o social, entre a normatividade vital e a normatividade social, partindo da visão ideal da totalidade social para posteriormente projetá-la no interior da natureza, que começa a funcionar como a imagem duplicada do que os setores hegemônicos da vida social procuram estabelecer como normalidade. Dessa forma, a biologização da política será o movimento complementar de uma verdadeira judicialização da vida, pois é a expressão da vida como o que se deixa pensar sob a forma das normas jurídicas e de nossos modelos de poderes e legitimidade. A vida será o fundamento da lei porque a lei encontrará na vida sua própria imagem invertida. A vida social poderá então mascarar para si a profunda "convergência de soluções paralelas" própria às normatividades sociais, paralelismo que produz conflitos contínuos sobre as normas e os valores que demonstram como a sociedade é um "conjunto mal unificado de meios" (Canguilhem, 2002, p. 229). Dessa forma, é possível compreender por que uma peça fundamental da reconstrução do pensamento crítico nas últimas décadas passou pelo esvaziamento ontológico da vida, produzido pelos desdobramentos do conceito de biopolítica reconstruído pelas estratégias foucaultianas.

No entanto, podemos atualmente colocar em questão a necessidade real de tal estratégia, pois mais eficaz do que esvaziar a realidade ontológica da vida talvez seja perguntar se as figuras totalitárias produzidas pela aproximação dos discursos da política e da biologia, com suas metáforas da sociedade como um organismo no qual lugares e funções estariam funcionalmente determinados, ou ainda através das temáticas do darwinismo social, não seriam resultantes de uma compreensão completamente incorreta do que é uma normatividade vital. Assim, ao invés de simplesmente cortar toda possibilidade de articulação entre os dois campos, há uma operação mais astuta que consiste em dar ao conceito de "vida" uma voltagem especulativa renovada.

Tal operação está claramente presente no professor de Foucault, a saber, Georges Ganguilhem. Lembremos, por exemplo, do sentido de uma afirmação como: "Não é porque sou um ser pensante, não é porque sou sujeito, no sentido transcendental do termo, é porque sou vivente que devo procurar na vida a referência da vida" (Canguilhem, 1983, p. 352).4 Posso pensar a vida porque não fundamento o pensamento a

4 Tal proposição segue de perto uma ideia nietzscheana: "Ao falar de valores, falamos sob a inspiração, sob a ótica da vida: a vida mesma nos força a estabelecer valores, ela mesma valora através de nós, ao estabelecermos valores" (Nietzsche, 2002, p. 36). Proposição que é distante de uma perspectiva biopolítica tipicamente foucaultiana por exigir que o conceito de vida seja dotado de potência produtiva autônoma do ponto de vista ontológico. Uma potên- 
partir da abstração de um sujeito transcendental que se colocaria como condição prévia para a categorização do existente, nem como substância pensante. Posso pensar a vida porque ela se expressa em minha condição de existente, e por ela ser o que faz da minha existência uma expressão, o movimento conceitual de meu pensamento não pode distanciar-se por completo da reprodução do movimento da vida. O que nos explica que: "não vemos como a normatividade essencial à consciência humana seria explicada, se ela não estivesse, de alguma forma, em germe na vida" (Canguilhem, 2002, p. 77). No entanto, se a normatividade essencial à consciência humana está "em germe na vida", então nada impedirá Canguilhem de dar um passo politicamente prenhe de consequências ao afirmar que: "os fenômenos da organização social são como que uma imitação da organização vital, no sentido em que Aristóteles diz que a arte imita a natureza. Imitar, no caso, não é copiar, e sim procurar reencontrar o sentido de uma produção" (p. 226). 5

Ao afirmar claramente que os fenômenos da organização social são como que uma imitação da organização vital, Ganguilhem mostra como seu conceito de vida não tem direito de cidadania apenas no interior de discussões sobre a clínica e as ciências médicas. Na verdade, ele tem uma forte ressonância para a crítica social, fornecendo uma espécie de horizonte biopolítico que não se resume à crítica foucaultiana da maneira pela qual a atividade vital é construída como categoria de normatização e legitimação de procedimentos disciplinares de "administração dos corpos e gestão calculista da vida". Ele traz em seu bojo a perspectiva positiva de uma biopolítica vitalista transformadora. ${ }^{6}$ Por partir de uma reflexão na qual a vida não aparece apenas como objeto reificado de práticas discursivas, mas também como a potência que produz conceitos, Canguilhem pode colocar no horizonte regulador do pensamento crítico algo como um peculiar fundamento biológico. O biológico, ou seja, a dimensão da vida que provoca em nós o espanto cuja resposta é uma forma de arquitetura de conceitos, não aparece assim apenas como produto de um discurso. Ele aparece como experiência que produz discursos, principalmente os discursos que permitem voltarmo-nos contra outros discursos que produzem em nós um profundo sentimento de limitação.

cia produtiva autônoma que pode levar-nos à pergunta sobre as possibilidades de uma política que assuma certa posição vitalista. Sobre a influência de Nietzsche em Canguilhem, cf. Canguilhem, 1990, p. 16-1; Daled, 2008, p. 115-40; Fichant, 1993, p. 48.

5 Pensando em afirmações desta natureza, Pierre Macherey dirá: "Assim, encontra-se invertida a perspectiva tradicional relativa à relação entre a vida e as normas. Não é a vida que é submetida a normas, estas agindo sobre ela do exterior, mas são as normas que, de maneira completamente imanente, são produzidas pelo movimento mesmo da vida" (Macherey, 2010, p. 102).

6 Isso talvez se explique pelo fato dos conceitos sobre a vida não serem, em Canguilhem, apenas objetos de uma epistemologia genealógica, mas também de uma peculiar ontologia. O que François Dagonet compreendeu ao lembrar que "enquanto Michel Foucault se engaja em um estudo genealógico, Georges Canguilhem explora menos o campo da história e entrega-se mais a um exame ontológico (em que consiste a saúde?)” (Dagonet, 1997, p. 15). 
Por outro lado, apelar à vida como fundamento para a crítica social teria a vantagem de retirar o pensamento crítico da dependência de filosofias da história que se veriam na obrigação de justificar perspectivas teleológicas, assim como uma confiança finalista no conceito de progresso. Tal apelo foi a estratégia maior no interior da filosofia francesa contemporânea e pode ser encontrado em experiências intelectuais tão distintas entre si quanto podem ser as de Henri Bergson, Georges Bataille, Gilbert Simondon e Gilles Deleuze. ${ }^{7}$

Claro que tal estratégia poderia ser, por sua vez, abstratamente criticada na medida em que potencialmente abriria as portas para a fascinação ideológica pela origem, uma origem agora naturalizada. A não ser que o conceito de vida tenha sido determinado de forma tal que ele tenha deixado de fornecer normas positivas de regulação das condutas, fornecendo apenas a descrição de um movimento processual imanente, ou seja, uma processualidade cuja teleologia encontra-se, de maneira imanente, no próprio processo; processualidade que Canguilhem descreve, como veremos, ao pensar a vida como atividade marcada pela errância. Nesse caso, a vida não fornece determinações ontológicas de forte teor prescritivo, ela fornece a possibilidade sempre aberta do que poderíamos chamar de "mobilidade normativa" do existente. Mobilidade que traz em seu bojo um modelo paradoxal de auto-organização. Trata-se então de compreender como uma normatividade vital pensada a partir da centralidade da noção de errância pode fornecer-nos uma recompreensão das potencialidades inerentes às articulações entre o político e o biológico. Trata-se ainda de compreender o modelo de processualidade que tal determinação da normatividade vital pressupõe. Para tanto, convém iniciar com uma precisão a respeito do sentido da noção de "norma” em Canguilhem.

\section{NoRmatividAdE VITAL E ERRÂNGIA}

Na verdade, a peculiaridade da posição de Canguilhem vem do fato de ele articular duas ideias que, aparentemente, seriam completamente contraditórias, a saber, normatividade e errância. Nosso conceito natural de normatividade parece distante de algo que poderíamos chamar de "errância". Por isso, por exemplo, afirmar que a relação entre a vida e as normas é completamente imanente, como parece ser o caso em Canguilhem, é uma afirmação que aparentemente não poderia ser levada até o extremo.

7 Ver, por exemplo, Bergson, 2007, Simondon e toda a primeira parte de Bataille, 2013, assim como Deleuze, que não verá problemas em dizer: "há um vínculo profundo entre os signos, o acontecimento, a vida, o vitalismo. É a potência de uma vida não orgânica, esta que pode estar em uma linha de desenho, de escritura ou de música. São os organismos que morrem, não a vida (...). Tudo o que escrevi era vitalista, ao menos eu espero, e constituía uma teoria dos signos e do acontecimento" (Deleuze, 1990, p. 196). 
No extremo, teríamos dificuldades em explicar porque há normas que vão contra a atividade vital por produzir um tipo de desconhecimento de tal atividade, um comportamento catastrófico que Canguilhem chama, sem deixar de esconder certo acento bergsoniano, de “mecanização da vida”. Na verdade, tal mecanização parece ser simplesmente indissociável da própria aplicação do conceito de norma.

Trivialmente, entendemos por "norma” um padrão de ordenamento baseado na regularidade e na padronização das expectativas de comportamento. O que explica por que é para nós tão difícil dissociar "norma” de uma certa força coercitiva. Por organizar nossa percepção a partir da identificação do caráter necessário de regularidades, a norma se imporia como uma forma de experiência do tempo marcado pela reprodução compulsiva do contínuo. Ou seja, viver sob o império da norma seria, necessariamente, viver no interior de um tempo regular desprovido de acontecimento, um tempo da redundância.

Lembremos ainda que normalmente vinculamos "norma" à capacidade de produzir julgamentos. Julgamentos seriam proposições que me comprometeriam com um determinado tipo de ação, já que "representar algo, falar sobre ou pensar em algo, é reconhecer sua autoridade semântica sobre a correção do comprometimento que alguém assume ao julgar" (Brandom, 2009, p. 35). Nesse sentido, emitir juízos sobre algo seria indissociável do ato de assumir a responsabilidade de agir de determinada forma. Tal responsabilização fundaria, por sua vez, uma identidade composta pela possibilidade da integração de julgamentos emitidos em vários momentos do tempo e que deveriam ser compatíveis entre si. Dessa forma, "deve-se integrar novos comprometimentos (endorsements) no todo que engloba nossos comprometimentos prévios" (p. 36).

Não é difícil perceber como a noção de norma aqui pressuposta deriva da experiência do ordenamento jurídico. Ela é a base não apenas para a produção de uma noção um tanto quanto simplista de responsabilização fundada na clareza semântica dos propósitos, clareza esta que pede a ausência de polivalência e de sobredeterminação na relação entre o julgamento e a ação; como se de um julgamento não pudéssemos derivar, sem perda de consistência, uma multiplicidade possível de ações, algumas mesmo contraditórias entre si. Ela pede ainda uma ideia de estabilidade da situação. Preciso integrar novos comprometimentos no todo que seria composto pelos comprometimentos prévios porque a situação na qual estou inserido seria, por sua vez, uma totalidade estável e regular. $\mathrm{O}$ mínimo que se pode dizer é que nada disso se refere à maneira pela qual Canguilhem compreende a dinâmica vital das normas.

É fato, dirá Canguilhem, que “a vida é atividade normativa”. Ela é atividade normativa, principalmente, porque todo organismo biológico age selecionando a partir de valores. É importante salientar tal aspecto para lembrar como a normatividade vital 
não é alguma forma de condicionamento, de ação reflexa determinada completamente pelo meio, mas atividade valorativa, um tipo de julgamento que, ao invés de apelar necessariamente à consciência, pode apelar aos afetos, às sensações e aos modos de afecções. As afecções julgam, por isso, "viver é, mesmo para uma ameba, preferir e excluir" (Canguilhem, 2002, p. 105). Tal atividade valorativa pressupõe a capacidade de estabelecer relações, de comparar contextos em vista ao fortalecimento da vida e é por pensar a experiência como um processo relacional baseado em valoração que Canguilhem conserva o termo "norma". Mas, nesse contexto, a atividade normativa não implica em absoluto regular o comportamento a partir de algo como uma consigna fixa. Ela indica, principalmente, uma "capacidade transitiva" (Canguilhem, 2009, p. 132), ou seja, uma capacidade de entrar em movimento, passando de uma situação à outra, recusando limitações. As normas vitais não conhecem determinações semânticas estáveis, já que são mera expressão da capacidade do organismo entrar em movimento. Não é por outra razão que Canguilhem dirá que a norma da vida é exatamente sua capacidade em mudar continuamente de norma. ${ }^{8}$

Poderíamos nos perguntar porque há propriamente "normatividade" nesta capacidade de entrar em movimento. Talvez porque mover-se implica, para o organismo, tanto ter a percepção de deslocar-se quanto deixar-se ou não se mover. Não apenas saber-se saindo de um ponto a outro, mas valorar tal movimento, querer se deslocar, tomar para si a fonte do movimento. Caso não houvesse tal valoração vinda do organismo, caso não houvesse alguma forma elementar de implicação intencional produzida pelo julgamento, ou ainda, caso não houvesse uma função implicativa expressa pelo organismo, teríamos um movimento completamente determinado pelo exterior e organismos seriam simplesmente estruturas condicionadas. No entanto, Canguilhem entende que o ato de julgar não é "uma operação lógica de recognição da realidade", mas capacidade de valoração concernente a todo vivente (cf. Franco, 2011, p. 77). Assim, se Canguilhem fala em normas é para determinar o organismo, e não o meio, como potência normativa, invertendo assim a direção normalmente pressuposta da atividade normativa. Como bem lembrou Badiou (2012, p 76), essa estratégia de inversão da direção da normatividade produz um espaço de múltiplos centros no qual o meio não pode mais ser uniforme. Pois falar da individualidade biológica do organismo como uma potência normativa é maneira de fazer da norma um procedimento de individualização contrário à ideia da normatividade do meio. Há uma potência normativa da individualidade biológica que produz formas singulares de relação com o meio, conse-

8 Assim, "as normas não são mais o que determinam direitos e obrigações impondo-se aos sujeitos de fora como no transcendentalismo moderno - permitindo fazer o que é permitido e proibindo o que não é permitido -, mas são a modalidade intrínseca que a vida assume em seu irrestrito poder de existir" (Esposito, 2008, p. 186). 
quência de uma peculiar estratégia de naturalização genérica de pressupostos implicativos e relacionais próprios a uma teoria do sujeito. Tal potência normativa fornece, ao organismo, a confiança para deslocar-se de um meio a outro, transformando sua resposta à imprevisibilidade do meio, com seus acontecimento aleatórios, sua contingência, em elemento para a criação de novas formas. Por isso, "a normalidade dos viventes é a qualidade da relação com o meio que permite a tais viventes, através das variações individuais de seus descendentes, novas formas de relação com um novo meio, e assim por diante" (Canguilhem, 2002, p. 132). Mas para compreender melhor a natureza dessa potência normativa da vida e seus desafios, devemos retomar as discussões de Canguilhem a respeito das distinções entre o normal e o patológico, entre a saúde e a doença.

\section{Quantidade e qualidade}

Ao focar suas reflexões nas distinções entre o normal e o patológico, Canguilhem pode defender que a atividade vital deve ser compreendida em sua dinâmica concreta. Mas a dinâmica concreta da vida é sua forma de ser "atividade de oposição à inércia e à indiferença" (Canguilhem, 2002, p. 208), pois não há indiferença biológica. Ao ser pensada como oposição, a vida traz para seu interior aquilo que lhe deve ser oposto, estabelecendo com ele uma relação de diferença interna. Esse oposto é pensado, por Canguilhem, a partir dos fenômenos de produção de "valores negativos", como a doença e o risco da morte. De fato, a noção de saúde absoluta é uma idealidade abstrata que está em contradição com a dinâmica própria a todos os sistemas biológicos. Por conseguinte, a saúde relativa é um estado de equilíbrio dinâmico instável, uma atividade constante de oposição. Talvez isso explique por que "a ameaça da doença é um dos elementos constitutivos da saúde" (p. 261). Pois, "se há um poder da vida, ele só se deve apreender através de seus erros e falhas, quando ele se choca contra obstáculos que impedem ou travam sua manifestação. Daí a importância constantemente reafirmada por Canguilhem dos 'valores negativos' cujo conceito funda sua perspectiva filosófica, uma perspectiva apoiada sobre a dialética, ou melhor, a dinâmica da potência e de seus limites" (Macherey, 2010, p. 124).

No entanto, não se trata de relativizar as distinções entre a saúde e a doença, o normal e o patológico. Canguilhem inicialmente se recusa a compreender a diferença entre o normal e o patológico como uma diferença quantitativa que diria respeito a funções e órgãos isolados, como se os fenômenos patológicos fossem, no organismo vivo, apenas variações quantitativas, déficits ou excessos. Nesse caso, o patológico é 
designado a partir do normal, daí porque ele será normalmente descrito como distúrbio, transtorno, déficit ou excesso que acontece no nível de funções e órgãos. Assim, “a doença não é pensada como uma experiência vivida, engendrando transtornos e desordens, mas como uma experimentação aumentando as leis do normal" (Le Blanc, 1998, p. 34). Em uma perspectiva positivista que nos remete diretamente a Auguste Comte e suas leituras de Broussais, a doença nada mais é do que um subvalor derivado do normal. É a definição do normal como padrão regular de atividade do organismo sob certo modelo de funcionamento do meio que define o campo da clínica. Esta experiência clínica exige que o normal esteja assentado em um campo mensurável acessível à observação. Tal campo privilegiado é a fisiologia, que aparece assim como fundamento para uma clínica que irá orientar-se a partir dos postulados da anatomia patológica e que se definirá a partir da indicação de “marcadores biológicos”. Nesse contexto, "as técnicas de intervenção terapêutica só podem ser secundárias em relação à ciência fisiológica, e isso na medida em que o patológico só tem realidade provisória por declinação do normal" (Canguilhem, 2002, p. 42).

Tomemos como exemplo ilustrativo desta tendência a definição de distúrbio mental (Mental disorder) fornecida pelo DSM-V:

um distúrbio mental é uma síndrome caracterizada por distúrbios clinicamente significantes na cognição individual, regulação emocional ou por comportamentos que refletem disfunções em processos psicológicos, biológicos ou de desenvolvimento subjacentes ao funcionamento mental (APA, 2013, p. 20).

Os distúrbios mentais seriam, a partir de tal perspectiva, fenômenos ligados diretamente a disfunções em processos específicos e individualizados. Assim, a patologia será conjugada em uma gramática de desregulação setorizada de funções. Teremos transtornos na capacidade de atenção, na constituição da personalidade, no desenvolvimento intelectual, na comunicação, nos afetos, na coordenação motora, no aprendizado, na alimentação, no sono, na sexualidade, entre tantos outros. Da mesma forma, a intervenção clínica deverá ser setorizada, focando-se na normalização da função.

A normalização, por sua vez, precisa de um sistema de medidas para orientar-se. Tomemos como exemplo os critérios diagnósticos da chamada "desregulação disruptiva do humor" (disruptive mood dysregulation disorder). Encontraremos descrições como: "várias explosões de temperamento que são claramente fora de proporção em intensidade ou duração em relação à situação ou provocação", “as explosões de temperamento são inconsistentes com o nível de desenvolvimento", "elas ocorrem, em média, três a quatro vezes por semana” (APA, 2013, p. 156). Ou seja, há um julgamento sobre a pro- 
porção adequada, sobre a consistência em relação a um processo de desenvolvimento psíquico pensado de maneira claramente padronizada e sobre a quantidade anormal de aparecimento do fenômeno. Mas não é possível falar em proporção excessiva, em consistência com momentos no interior de um processo de desenvolvimento e em quantidade normal, se o julgamento sobre a doença não pressupor padrões claramente estabelecidos e mensuráveis de normalidade. É da desregulação em relação a tais padrões que versa o discurso sobre a patologia. Tais padrões estão pressupostos sem estarem completamente postos, já que em momento algum eles são claramente apresentados, o que produz uma situação disciplinar evidente. A normalidade da "regulação emocional" será aquela que melhor adaptar-se aos critérios de rendimento e adaptabilidade partilhados por uma rede implícita de assentimento social da qual o próprio médico faz parte.

Contra os modelos dessa natureza de reflexão sobre as patologias, Canguilhem procura recuperar os postulados de uma teoria dinamista que encontra na medicina grega seu exemplo fundador. Seu pressuposto central é compreender a doença como um acontecimento que diz respeito ao organismo vivo encarado na sua totalidade. Pois não haveria um único fenômeno que se realize no organismo doente da mesma forma como no organismo são.

Quando classificamos como patológico um sistema ou um mecanismo funcional isolado, esquecemos que aquilo que os tornam patológicos é a relação de inserção na totalidade indivisível de um comportamento individual. Há uma diferença qualitativa fundamental que atinge todo o organismo com a integralidade de seus processos e funções. Canguilhem chega mesmo a afirmar que estar doente é, para o homem, viver uma vida diferente, é passar por uma modificação global de conduta. Notemos ainda que tal estratégia de vincular o normal a uma relação com o meio implica afirmar não haver fato algum que seja normal ou patológico em si. Eles são normal e patológico no interior de uma relação entre organismo e meio ambiente. Não há uma continuidade quantitativa entre o normal e o patológico, mas uma descontinuidade qualitativa. Canguilhem não nega que as diferenciações quantitativas estejam presentes na diferenciação entre o estado doente e o estado normal. No entanto, quando entram na definição do patológico como variação quantitativa do normal, termos como "mais" e "menos" não têm uma significação puramente quantitativa. "Hegel sustenta que a quantidade, por seu aumento ou diminuição, transforma-se em qualidade. Isso seria absolutamente inconcebível se uma relação como qualidade não persistisse ainda na qualidade negada que chamamos de quantidade" (Canguilhem, 2002, p. 83). 
Uma gerta latitude: Georges Canguilhem, biopolítica e vida como errância

\section{O ABISMO DA IMPOTÊNGIA}

De fato, a clínica procura, através de noções anatômicas, fisiológicas ou neuronais, determinar a realidade da doença, mas essa realidade, a clínica só a percebe através da consciência de decréscimo da potência e das possibilidades de relação com o meio, consciência esta veiculada primeiramente pelo sujeito que sofre. "Patológico implica pathos, sentimento direto e concreto de sofrimento e impotência, sentimento de vida contrariada" (Canguilhem, 2002, p. 106). Enquanto modificação global da conduta, a doença é indissociável da restrição da capacidade de ação. Como dizia Goldstein (1983, p. 346), estar doente é "não estar em estado de atualizar a capacidade de rendimento que lhe pertence essencialmente”. Ou seja, há uma especificidade da restrição da capacidade de ação na doença. ${ }^{9}$ Ela não é resultado de uma coerção externa, mas de uma impossibilidade interna ao organismo de atualizar seus possíveis, obrigando-se assim a "viver em contrariedade". Por isso, Canguilhem (2002, p. 91) fala da doença como "abismo da impotência".

Há duas consequências importantes derivadas dessa definição de doença. A primeira é vincular, de maneira essencial, doença e consciência da doença. De fato, a inserção de noções vinculadas a distinções qualitativas na diferenciação entre o normal e o patológico pode parecer uma porta aberta para derivas subjetivistas, já que a determinação da qualidade é uma operação valorativa que depende, em última análise, da expressão da subjetividade do doente. O mundo do doente é qualitativamente diferente porque o doente avalia o decréscimo em sua capacidade funcional e em sua dispo-

sição. É para evitar tal dependência em relação a operações valorativas, em relação à expressão da subjetividade do doente, sempre incerta e insegura, que René Leriche dirá, no volume vi da Encyclopédie Française, de 1936: "se quisermos compreender a doença, é necessário desumanizá-la", ou ainda, "na doença, o que menos importa é o homem".

De certa forma, Canguilhem parte de tais afirmações para defender o contrário, a saber, que o patológico só começa quando é reconhecido como tal pela consciência marcada pela experiência da doença. Com um certo acento hegeliano, Canguilhem (2002, p. 68) não teme afirmar que "não há nada na ciência que antes não tenha aparecido na consciência". Não se trata necessariamente da consciência do sujeito que atualmente sofre, mas naquelas dos que outrora sofreram e que forneceram ao saber médico a orientação do seu olhar. Se o médico pode adiantar-se à consciência que seu paciente tem da doença é porque, outrora, a doença foi sentida como tal por alguma

9 Assim: "nos dirigimos a uma concepção mais relacional que substancialista ou essencialista da saúde e da doença na medida em que a capacidade normativa do indivíduo enraiza-se, para Canguilhem, na sua relação com o meio" (Giroux, 2010, p. 30). 
consciência. "Sempre se admitiu, e atualmente é uma realidade incontestável, que a medicina existe porque há homens que se sentem doentes, e não porque existem médicos que os informam de suas doenças" (2002, p. 69).

Uma proposição dessa natureza é passível de vários mal-entendidos porque parece convidar a uma deriva subjetivista insustentável para a definição da partilha entre o normal e o patológico. Afinal, a patologia é um conhecimento objetivo ou é o resultado do sentimento subjetivo do paciente? Na verdade, Canguilhem tem em vista o fato de que:

(...) não há ciência da fisiologia humana sem técnica de restauração da saúde, ou seja, sem a consciência da doença por um sujeito. Uma nova afirmação resulta disso: a anterioridade da clínica, experiência da doença partilhada entre o doente e o médico, sobre a fisiologia e a patologia (Debru, 2004, p. 33).

No entanto, esse apelo a uma espécie de "consciência histórica" pressuposta pelas experiências anteriores de sofrimento é impreciso. Pois, no limite, ele nos levaria a não mais dissociar doença e anomalia. Fato problemático, pois uma anomalia vivenciada de maneira patológica por uma individualidade em determinada situação pode aparecer, para outra individualidade em outra situação, como a ocasião para o desenvolvimento de novas normatividades. Daí porque a fronteira entre o normal e o patológico é imprecisa quando tomamos diversas individualidades consideradas simultaneamente, mas ela é absolutamente precisa quando tomamos uma individualidade considerada sucessivamente. Vem mais uma vez de Goldstein a ideia, presente em Canguilhem, que a distinção entre o normal e o patológico exige uma norma individualizada. Não se trata aqui, no entanto, de uma concepção individualista de saúde, mas de uma concepção "que individualiza". A saúde não é um padrão que conforma individualidades a um conjunto predeterminado de regularidades a serem observadas. Padrão disciplinar que visaria, no caso humano, produzir indivíduos como entidades capazes, por exemplo, de organizar sua conduta a partir de "regulações emotivas" e "processos cognitivos" socialmente normatizados. Ela é, na verdade, a capacidade de individualizar processos tendo em vista a constituição de inflexões singulares da vida. A saúde não é uma conformação, mas uma individuação que produz processos que, do ponto de vista dos interesses de autoconservação dos indivíduos de uma espécie, podem inclusive parecer irracionais.

Isso auxilia, entre outras coisas, a compreender a importância da desvinculação geral entre doença e anomalia. ${ }^{10} \mathrm{Nem}$ toda anomalia é patológica, o que não significa

$10 \mathrm{O}$ que não poderia ser diferente, já que, como veremos mais à frente, "a negatividade da doença (e principalmente da morte) não está ligada à modificação de uma norma propriamente originária, como fizeram as teorias da dege- 
que inexistam anomalias patológicas. Mas quando "a vida não se contraria”, uma individualidade em mutação é o ponto de partida para outra espécie, pois exprime outras formas de vida possíveis que, caso demonstrem sua superioridade em relação à fecundidade, à variabilidade e à estabilidade da vida, serão novas normatividades.

Não existe fato que seja normal ou patológico em si. A anomalia e a mutação não são, em si mesmas, patológicas. Elas exprimem outras normas de vida possíveis. Se essas normas forem inferiores às normas anteriores, serão chamadas patológicas. Se, eventualmente, revelarem-se equivalentes - no mesmo meio - ou superiores - em outro meio - serão chamadas normais. Sua normalidade advirá de sua normatividade (Canguilhem, 2002, p. 113).

Assim, se a saúde pode produzir uma individuação que parece irracional a partir da perspectiva da autoconservação dos indivíduos de uma espécie localmente configurada é porque ela é a expressão da mobilidade da vida em sua procura por formas fora da espécie:

Há uma polaridade dinâmica da vida. Enquanto as variações morfológicas ou funcionais sobre o tipo específico não contrariam ou não invertem essa polaridade, a anomalia é um fato tolerado; em caso contrário, a anomalia é experimentada como tendo valor vital negativo e se traduz externamente como tal (Canguilhem, 2002, p. 105).

Ou seja, a vida é uma atividade normativa polarizada contra tudo o que é valor negativo, tudo o que significa decréscimo e impotência. Quando a diversidade orgânica não implica tal polarização, a diferença não aparece como doença. Por isso, os seres vivos que se afastam do tipo específico são, muitas vezes, inventores a caminho de novas formas. Se a saúde é norma que individualiza, é porque ela produz normas a partir de anomalias que se demonstraram produtivas. Na verdade, toda verdadeira saúde é uma espécie de anomalia produtiva, todas as formas vivas são "monstros normalizados" (Canguilhem, 2003, p. 206). ${ }^{11} \mathrm{O}$ que não poderia ser diferente já que a vida, mesmo no

neração. Ao contrário, ela está ligada à incapacidade do organismo modificar a norma aprisionando-o, forçando-o a uma repetição infinita da norma" (Esposito, 2008, p. 190).

11 Sobre tal relação entre anomalia e produção de normatividades vitais, vale a pena ainda lembrar que "graças à perfeição conservadora do aparelho replicativo, toda mutação, considerada individualmente, é um acontecimento muito raro. Nas bactérias, únicos organismos dos quais temos dados numerosos e precisos a esse respeito, podemos admitir que a probabilidade, para um gene dado, de uma mutação que altera sensivelmente as propriedades funcionais da proteína correspondente é da ordem de $10^{-6}$ a $10^{-8}$ por geração celular. Mas, em alguns mililitros de água, 
animal, não é mera capacidade de evitar dissabores e conservar-se. Ela é procura, atividade baseada na "capacidade de afrontar riscos e triunfar" (p. 215), daí porque ela tolera monstruosidades. Não estamos muito longe das afirmações de Nietzsche que procuram erigir a criação de valores em vontade de afirmação da vida a partir do conceito de "grande saúde".

\section{Patologias sociais}

Notemos, entre outras coisas, o impacto político de uma ideia dessa natureza. Ao utilizar os conceitos de normal e patológico para dar conta da vida social, Émile Durkheim dirá que "para as sociedades como para os indivíduos, a saúde é boa e desejável, a doença, ao contrário, é a coisa má que deve ser evitada” (1988, p. 1422). O paralelismo assumido entre indivíduo e sociedade através do uso sociológico de um vocabulário médico permite a Durkheim falar da última como de um "organismo" ou de um "corpo" que precisa de intervenções a fim de livrar-se de acontecimentos que a enfraquecem e a fazem adoecer. Por outro lado, essa visão orgânica do social leva Durkheim a insistir na dependência profunda entre o sofrimento psíquico e o sofrimento social a partir da relação entre o todo e suas partes, como podemos ver em uma afirmação como:

Os indivíduos participam muito estreitamente da vida da sociedade para que ela possa ficar doente sem que eles sejam tocados. Seu sofrimento advém necessariamente do sofrimento deles. Como ela é o todo, o mal que ela sente se comunica às partes que a compõem (Durkheim, 2000, p. 229).

Mas o ponto importante aqui é como se descobre a normalidade do organismo social. Ela é descoberta através da construção de um tipo médio derivado da ideia de média aritmética, o que leva a discussão sobre o patológico a derivar-se, em larga medida, da noção de desvio quantitativo em relação à norma. ${ }^{12} \mathrm{O}$ patológico será, assim, um problema de excesso ou de falta em relação ao tipo normal previamente definido através do recurso à média. Essa maneira de definir a normalidade a partir do tipo médio obriga Durkheim a estabelecer uma indistinção importante entre o patológico e a ano-

uma população de vários bilhões de células podem desenvolver-se. Em tal população, temos a certeza de que toda mutação dada é representada em 10, 100 ou 1.000 exemplares. Podemos igualmente estimar que o número total de mutantes de todas as espécies nessa população é da ordem de $10^{5}$ a $10^{6}$. Na escala de uma população, a mutação não é um fenômeno de exceção, é a regra” (Monod, 1970, p. 157).

12 "Nós chamaremos de normais os fatos que apresentam as formas mais gerais e nós daremos aos outros o nome de mórbidos ou de patológicos” (Durkheim, 2000, p. 149). 
malia, como vemos em uma afirmação como "o mórbido é o anormal na ordem fisiológica tal como o teratológico é o anormal na ordem anatômica” (2000, p. 149). Pois a anomalia é a figura privilegiada de um tipo que não pode mais ser descrito em conformidade aos padrões de uma estrutura média.

Aqui, devemos fazer uma precisão. A princípio, pode parecer estranho que Durkheim se recuse, por exemplo, a chamar o crime ou o suicídio de patologias. Ao contrário, "o crime é normal porque uma sociedade sem crime é impossível" (2000, p. 160). Pois através do crime uma sociedade fortaleceria os sentimentos coletivos ofendidos, principalmente em uma época na qual as trajetórias individuais significam, também, intensidades distintas da consciência moral. Por outro lado, "para que ela possa evoluir, faz-se necessário que a originalidade individual possa aparecer à luz do dia. Ora, para que a originalidade do idealista, que sonha ultrapassar seu século, possa manifestar-se, é necessário que aquela do criminoso, que está atrás de seu tempo, seja possível. Uma não vai sem a outra" (p. 164). Essa compreensão dinâmica da sociedade permite a Durkheim afirmar que a liberdade nunca seria proclamada, se as regras que a proibiam não fossem violadas antes de serem ab-rogadas. No entanto, nesse momento tal violação foi um crime. Da mesma forma, o suicídio é normal, porque não há sociedade sem um certo nível de suicídio (p. 10). Através dos suicídios uma sociedade mostra sua força diante dos indivíduos (como no caso do suicídio altruísta) ou se fortalece contra um individualismo excessivo (como no caso do suicídio egoísta). Crime e suicídio são "imperfeições necessárias”, mas não doenças.

Se nem o crime nem o suicídio são, em si, patologias é porque o conceito não se refere a fenômenos sociais específicos que encontram seu lugar no desenvolvimento dinâmico da vida social e que, pela via negativa, reforçam seus sistemas de crenças. Na verdade, a noção de patologia social é utilizada por Durkheim para descrever a desagregação da força de reprodução da vida social. Isso explica porque o conceito de anomia aparecerá como a patologia social por excelência. Ela descreve uma forma de desvio marcada pela falta e pela ausência, já que a desregulação das normas indica incapacidade de determinar sujeitos, internalizando sistemas de regras de conduta e crenças, devido à falta de força de coesão social. Dessa maneira, as normas sociais não seriam mais capazes de individualizar comportamentos e fundamentar funções sociais de maneira bem sucedida.

Nesse sentido, é claro o modo pelo qual Canguilhem praticamente coloca tal perspectiva de Durkheim de cabeça para baixo. Não sendo o normal aquilo derivado do nível médio presente nas "formas mais gerais", nem sendo as anomalias necessariamente expressões de patologias, elas podem aparecer como a expressão da capacidade transitiva da vida em sua procura para deslocar-se de um meio a outro. Do ponto de vista da normatividade social vigente na procura de sua conservação, mesmo que através de 
uma dinâmica de fortalecimento que admite o desvio controlado, toda anomalia é um convite em potencial à anomia. Porque a anomalia é o não determinável, o sem lugar. No entanto, essa ausência de lugar pode não ser simples desabamento da estrutura, mas a possibilidade de um modelo diferente de produtividade.

Assim, patológico para Canguilhem não será o anormal, mas exatamente o deixar-se aprisionar na fixidez de uma configuração estática da estrutura das normas. Longe de impor uma normatividade reguladora única a nossas expectativas de realização, o conceito de vida permite expor a raiz da profunda a-normatividade e indeterminação que nos parece guiar no interior dos embates na vida social. Pois "o que caracteriza a saúde é a capacidade de ultrapassar a norma que define o normal momentâneo, a possibilidade de tolerar infrações à norma habitual e de instituir novas normas em situações novas" (Canguilhem, 2002, p. 151). Se quisermos explorar as possibilidades do uso de conceitos como "patológico" na análise da vida social, diremos que a saúde exige uma experiência na qual a capacidade de ultrapassar normas vigentes, de afirmar o que aparece como anômalo, assim como o poder de instituir novas normatividades, sejam fenômenos internos às dinâmicas sociais e políticas.

\section{O QUe Pode Significar "DOMINAR"}

Neste ponto, fica clara a importância dada por Canguilhem (2002, p. 14,6) à dissociação entre a saúde e a adaptação ao meio. Importância sintetizada em afirmações como: "normal é viver em um meio no qual as flutuações e os novos acontecimentos são possíveis", ou ainda, "o homem só se sente em boa saúde - que é, precisamente, a saúde quando se sente mais do que normal, isto é, não apenas adaptado ao meio e às suas exigências, mas também normativo, capaz de seguir novas normas de vida" (p. 161). São maneiras de afirmar que a saúde dissocia "normalidade" e "normatividade" por ser uma atividade capaz de "colocar em questão as normas fisiológicas usuais", permitindo ao organismo viver um mundo de acidentes possíveis.

A saúde, como expressão do corpo produzido, é uma segurança vivida em um duplo sentido de segurança contra o risco e de audácia para corrê-lo. É o sentimento de uma capacidade de superação das capacidades iniciais, capacidade de levar o corpo a fazer o que ele parecia inicialmente não ser capaz de prometer" (Canguilhem, 1990a, p. 26). 
O que implica uma noção de relação entre o organismo e o meio ambiente que não pode ser compreendida como simples adaptação e conformação a um sistema metaestável. Um organismo completamente adaptado e fixo é doente por não ter uma margem que lhe permita suportar as mudanças e infidelidades do meio. Por isso, compreendemos mal um organismo biológico quando vemos nele apenas um feixe de funções e órgãos que se submetem a padrões gerais de mensuração e quantificação, feixe de funções que responde a exigências de ajustamento a um meio causalmente fechado. Essa vida seria o exemplo de uma razão que se transformou em princípio de autoconservação; princípio que tem em vista apenas as ilusões mecanicistas de uma visão de natureza digna do século xIx. Vida mutilada por não reconhecer mais sua potência de produção de valores. Por isso, a doença aparece necessariamente como fidelidade a uma norma única. Ela é o nome que damos a uma norma de vida que não tolera desvio algum das condições em que é válida. Daí a definição:

uma vida sã, uma vida confiante na sua existência, nos seus valores, é uma vida em flexão, uma vida flexível (...). Viver é organizar o meio a partir de um centro de referência que não pode, ele mesmo, ser referido sem com isso perder sua significação original (Canguilhem, 2003, p. 188).

Tentemos entender melhor o que pode vir a ser essa flexibilidade própria à vida. Ser flexível é, principalmente, ser capaz de mover-se. Se aceitarmos a teoria da degenerescência, seremos obrigados a admitir que a cura da doença implica necessariamente alguma forma de retorno a estados anteriores ao adoecer, estados nos quais as funções vitais ligadas à preservação e geração poderiam voltar a funcionar a contento. No entanto, uma forma insidiosa da própria doença é a fixação em um estado anterior de saúde. Pois a vida não conhece reversibilidade, embora ela admita reparações que são inovações fisiológicas. Goldstein insistia que "não se pode jamais reencontrar a antiga maneira de agir, a antiga adaptação ao antigo meio que correspondia à essência do organismo são" (1983, p. 348). A nova saúde não é a saúde de outrora, nem é a recuperação de determinações normativas anteriores. Mas, mais importante, ela é indissociável de uma compreensão renovada do que significa "seguir uma norma". Pensemos, por exemplo, na seguinte afirmação de Canguilhem.

Porque a saúde não é uma constante de satisfação, mas o a priori do poder de dominar situações perigosas, esse poder é usado para dominar perigos sucessivos. A saúde, depois da cura, não é a saúde anterior. A consciência do fato de que curar não é retornar, ajuda o doente em busca de um estado de menor renúncia possível, liberando-o da fixação ao estado anterior (Canguilhem, 2000, p. 7०). 
O que pode ser, neste contexto, "o a priori do poder de dominar situações perigosas"? Se entendermos "dominar" como submeter o funcionamento de uma situação à imagem de ordenamento estabelecida a priori ou previamente, dificilmente entenderemos o que Canguilhem tem em mente. Senão, seria impossível compreender por que curar não poderia ser, de alguma forma, retornar. No caso, retornar a imagens de ordenamento anteriormente estabelecidas.

Lembremos aqui de uma afirmação astuta de Theodor Adorno, para quem só dominamos uma língua quando nos deixamos dominar por ela, ou seja, quando nosso raciocínio é levado, em certa medida, pela estrutura interna da língua. Talvez algo disto valha para o fenômeno que Canguilhem procura descrever. O poder de dominar situações perigosas é, de certa forma, indissociável da capacidade de deixar-se dominar por perigos sucessivos. Se aceitarmos que tais "perigos" representam as situações que podem levar à desorganização e à desordem do organismo, até sua completa dissolução e morte, então diremos que dominar tais situações é indissociável da capacidade de ser "um sistema em desequilíbrio incessantemente compensado por empréstimos do exterior" (Canguilhem, 1990b, p. 1077). Conceito aparentemente paradoxal, já que um sistema em desequilíbrio incessante é aquele que transforma o risco perpétuo de sua dissolução enquanto sistema em operador de seu desenvolvimento, é aquele que cria e desenvolve habilidades a partir do que pareceria refratário a toda criação técnica. Desequilíbrio que nos coloca diante de um dos conceitos fundamentais de Canguilhem, a saber, a noção de errância.

\section{O QUE AGONTECE QUANDO ENTRAMOS POR UMA PORTA ERRADA?}

Canguilhem costumava dizer que a doença poderia ser definida como um erro, não no sentido de fazer uma conta errada, mas de entrar por uma porta errada. Se voltarmos à primeira definição de doença como restrição da capacidade de ação através da fixação a uma norma única, então é possível completar o raciocínio explorando um duplo movimento. A doença aparece como reação catastrófica à percepção da instabilidade do meio no qual o organismo se situa. Assim, o organismo erra por agir como se tomasse o meio a partir de sua imagem de estabilidade, ligada à perpetuação da situação anterior. Ele continua reagindo mecanicamente, como se o meio não se houvesse modificado, o que o leva a sobreviver apenas sob a condição de restringir radicalmente seu meio e a sucumbir quando essa restrição é impossível.

Mas o que pode significar aqui "entrar pela porta errada"? Quem entra pela porta errada não apenas se perde, mas encontra o imprevisto, o impercebido que só vem à 
existência quando mudamos a estrutura de nossa percepção. Entrar pela porta errada é a condição para que as mutações estruturais do organismo ocorram. No entanto, em uma afirmação importante a respeito de seu conceito de errância, Canguilhem dirá que "nada acontece por acaso, mas tudo ocorre sob a forma de acontecimentos. É nisso que o meio é infiel. Sua infidelidade é exatamente seu devir, sua história" (2002, p. 159). O que pode significar essa aparente negação do acaso e sua inusitada contraposição à noção de acontecimento? Podemos tentar contemporizar afirmando que talvez esse regime de negação do acaso deva ser melhor qualificado, talvez ele seja simplesmente expressão da recusa em admitir acontecimentos desprovidos de relação. Não que Canguilhem procure assumir a submissão de todo acontecimento possível a relações de causalidade determinada. Caso assim fosse, eliminaríamos por completo a função da contingência no processo de desenvolvimento das formas vitais.

Nesse contexto, "nada acontece por acaso" significa simplesmente que nada acontece sem impor um devir que reconfigura as possibilidades do organismo, definindo retroativamente uma história. A necessidade não é uma determinação ontológica inscrita previamente no interior das formas vitais. Formas vitais não resultam de um projeto que se projetaria no tempo em vistas de sua realização. A necessidade é uma determinação processual que fornece à historicidade a função de construir relações entre as contingências. Pois a errância não é uma sucessão de contingências que não tecem entre si relação alguma, o que nos levaria à ideia de um sistema que vive em um tempo completamente descontínuo, um tempo pontilhista e instantaneista no interior do qual habitariam organismos que seriam tábulas rasas perpétuas. Mesmo no nível das estruturas celulares tal ideia do tempo da vida como um tempo descontínuo não se sustenta:

(...) a resposta de uma célula às modificações de seu meio ambiente não é unívoca. Sua resposta depende, ao mesmo tempo, da natureza dos sinais [que ela recebe do exterior], do momento no qual ela os percebe e do estado no qual ela se encontra. Sua resposta depende, ao mesmo tempo, de seu presente e de sua história, dos sinais que ela recebeu no passado e da maneira com a qual ela os interpretou (Ameisen, 2003, p. 51).

A vida tem memória, hábito, repetição, um pouco como um pianista cujos dedos ao piano relembram uma peça que a consciência é incapaz de recompor. As atividades anteriores ficam marcadas como pontos de um processo contínuo de recomposição dinâmica a partir das pressões do presente. Por isso, o trajeto vital de metamorfoses não é indiferente, mesmo que ele seja recontado "de frente para trás". 
No entanto, a errância não é movimento submetido a uma finalidade teleológica transcendente e é para afirmar tal característica que devemos insistir na existência da contingência. ${ }^{\mathbf{1 3}}$ Nesse sentido, vale a pena lembrar da peculiaridade da processualidade interna à vida. Para assumirmos que organismos podem ter a experiência da contingência devemos aceitar que o organismo biológico é uma organização dinâmica capaz de ser um processo de

desorganização permanente seguido de reorganização com aparição de propriedades novas, se a desorganização pode ser suportada e não matou o sistema. Dito de outra forma, a morte do sistema faz parte da vida, não apenas sob a forma de uma potencialidade dialética, mas como uma parte intrínseca de seu funcionamento e evolução. Sem perturbação ou acaso, sem desorganização, não há reorganização adaptadora ao novo; sem processo de morte controlada, não há processo de vida (Atlan, 1979, p. 280).

Aqui se delineia a diferença ontológica fundamental entre um organismo e uma máquina artificial. Ao menos segundo Canguilhem, "na máquina, há verificação estrita das regras de uma contabilidade racional. O todo é rigorosamente a soma das partes. O efeito é dependente da ordem das causas" (2003, p. 149). Já o organismo não conhece contabilidade.

Uma fiabilidade como essa do cérebro, capaz de funcionar com continuidade mesmo que células morram todos os dias sem serem substituídas, com mudanças inesperadas de irrigação sanguínea, flutuações de volume e pressão, sem falar da amputação de partes importantes que perturbam apenas de maneira muito limitada as performances do conjunto não tem semelhança com qualquer autômato artificial (Atlan, 1979, p. 41).

Ou seja, há um princípio de auto-organização no organismo capaz de lidar com as desestruturações profundas e as desordens. Isso é possível porque um sistema reduzido a uma só via de contato (entre A e B) seria simplesmente dissolvido, se tal via se desordenasse por completo. Mas os organismos não são sistemas dessa natureza.

13 Insistindo na natureza dos erros que modificam a instrução genética produzindo mutações que podem ter consequências importantes para a espécie, François Jacob dirá que "todo o sistema é agenciado para produzir erros às cegas. Não há na célula constituinte algum para interpretar o programa em seu conjunto, para sequer "compreender' uma sequência e modificá-la. Os elementos que traduzem o texto genético só compreendem a significação de trincas tomadas separadamente. Esses elementos que, ao reproduzi-los, poderiam modificar o programa, não o compreendem. Se existisse uma vontade para modificar o texto, ela não disporia de ação direta alguma. Ser-lhe-ia necessário passar pelo longo desvio da seleção natural" (Jacob, 1970, p. 310). 
Ao contrário, eles são compostos por vários subsistemas que permitem que a completa independência entre A e B não se traduza na dissolução completa do organismo. ${ }^{14}$

No entanto, a possibilidade da destruição do organismo como sistema é um dado real e é necessário que tal dado seja real para que a ideia de errância possa realmente ser necessária. Errância implica poder se perder por completo, dispender todo o processo acumulado em uma profunda irracionalidade econômica, o que explica porque a destruição do sistema é uma parte intrínseca de seu funcionamento. Pois apenas por poder perder-se por completo, ou seja, por poder deparar-se com a potência do que aparece como a-normativo, que organismos são capazes de produzir formas qualitativamente novas, migrar para meios radicalmente distintos e, principalmente, viver em meios nos quais acontecimentos são possíveis, nos quais os acontecimentos não são simplesmente o impossível que destrói todo princípio possível de auto-organização. Tal figura do acontecimento demonstra como as experiências do aleatório, do acaso e da contingência são aquilo que tensionam o organismo com o risco da decomposição. São tais experiências ligadas à errância que dão à vida sua "normatividade imanente" (Muhle, 2008, p. 106).

Não deixa de ser surpreendente que a vida sirva-se dessa dinâmica para poder construir suas formas, o que talvez mostre como não se trata de um mero dado anedótico lembrar que "mais de noventa e nove por cento das espécies aparecidas desde quatro bilhões de anos foram provavelmente extintas para sempre" (Ameisen, 2003, p. 12). Esta é apenas uma maneira um pouco mais dramática de lembrar que os valores mobilizados pela atividade vital não podem ser a "utilidade", a "função" ou mesmo o "papel" a desempenhar. A vida ultrapassa essa contabilidade de balcão de supermercado. Não podemos sequer definir o desenvolvimento de órgãos a partir da necessidade de certas funções próprias a uma adaptação à configuração atual do meio. Como a biologia evolucionista nos mostra, mais correto seria dizer que muitos órgãos são inicialmente configurados para que, posteriormente, uma multiplicidade de funções deles se desenvolvam.

A natureza paradoxal de um sistema que funciona através da errância vem do fato dele estar assentado sobre a ausência de uma tendência a "perseverar no seu próprio ser”. Para que haja uma errância que não seja simplesmente movimento de expressão do desenvolvimento biológico em direção ao progresso contínuo, devemos aceitar a

14 Tendo tal modelo em mente, Atlan dirá, a respeito do cérebro, que “a determinação genética concerne apenas à estrutura anatômica global do cérebro, sendo o detalhe das conexões fruto do acaso, modificando-se à medida de sua constituição pelo efeito de experiências adquiridas", pois, "se representamos um organismo em relação a um meio ambiente natural e impessoal, os efeitos deste só podem ser percebidos como aleatórios em relação à estrutura e às determinações anteriores do organismo. É por isso que a ideia de que uma parte importante seja deixada ao acaso na estrutura do detalhe da organização cerebral permite resolver esse paradoxo aparente relativo a um sistema organizado que parece ampliar a riqueza de sua organização sob efeito de fatores aleatórios" (Atlan, 1992, p. 165). 
existência de uma tendência à "dilapidação de si" interna aos organismos. O que talvez explique porque Canguilhem nunca viu reais dificuldades em admitir, por exemplo, o fundamento biológico de um conceito como o de pulsão de morte freudiana. ${ }^{\mathbf{5}}$ Essa tendência à dilapidação de si foi descrita posteriormente através de fenômenos como a apoptose, ou seja, a morte celular produzida por um princípio interno.

Durante muito tempo, pensamos que o desaparecimento de nossas células - assim como nossa própria desaparição como indivíduos - só podia resultar de acidentes e de destruições, de uma incapacidade fundamental a resistir à usura, à passagem do tempo e às agressões permanentes do meio ambiente (...). Hoje, sabemos que todas nossas células possuem o poder de autodestruírem-se em algumas horas (...). E a sobrevivência de cada uma de nossas células depende, dia após dia, de sua capacidade de perceber no meio ambiente de nosso corpo os sinais emitidos por outras células, e apenas tais sinais lhes permitem reprimir o desencadeamento de sua autodestruição (...) um acontecimento percebido até aqui como positivo - a vida - parece resultar da negação de um acontecimento negativo - a autodestruição (Ameisen, 2003, p. 15).

Ou seja, viver, para cada célula, é ter conseguido reprimir o desencadeamento de seu suicídio, é negar uma negação (como dizia Rubens Rodrigues Torres Filho, quem um dia adoeceu de hegelianismo nunca se cura). Tal ideia produz consequências importantes para o conceito de auto-organização. Pois os sistemas orgânicos, devido à constância dos erros de leitura, teriam uma tendência interna à decomposição e à desordem que pode levar ou à autodestruição ou a ser agenciados através da errância, com todos seus riscos e suas reorganizações provisórias. Daí porque "viver, construindo-se em permanência, é utilizar instrumentos que podem provocar a autodestruição e ser, ao mesmo tempo, capaz de reprimir tal autodestruição" (Ameisen, 2003, p. 316). ${ }^{16}$

15 Como dirá Canguilhem, "se é verdade que o vivente é um sistema em desequilíbrio incessantemente compensado por empréstimos ao exterior, se é verdade que a vida está em tensão com o meio inerte, o que haveria de estranho ou de contraditório na hipótese de um instinto de redução de tensões a zero, de uma tendência à morte?" (Canguilhem, 1990b, p. 1068). Canguilhem pensa, sobretudo, em afirmações de Henri Atlan, para quem o único projeto possível dos organismos biológicos é morrer, “ou seja, como em todo sistema físico, de alcançar um estado de equilíbrio. Os algoritmos do mundo vivente não podem ser inicialmente algoritmos de reprodução de estados de equilíbrio, mas de distâncias em relação ao equilíbrio, assim como de retorno a tal estado por desvios (...). Como nota Ashby, o retorno ao equilíbrio só é banal e desinteressante, do ponto de vista de algoritmos de organização, em sistemas simples. Em sistemas complexos, unicamente devido ao grande número de parâmetros que podem variar ao mesmo tempo, os estados de estabilidade fora do equilíbrio, e os caminhos utilizados para tornar ao equilíbrio, oferecem possibilidades de organização muito mais ricas" (Atlan, 1992, p. 224).

16 Há de se pensar tal proposição à luz de uma afirmação de Gilles Deleuze (1969, p. 188): “Se nós perguntamos por que a saúde não seria suficiente, porque a rachadura é desejável, é porque só se pensou através dela e sobre suas 
A mecanização da vida descrita através dos fenômenos de doença não é apenas uma reação catastrófica contra um meio ambiente em mutação. Ela é também incapacidade em agenciar tendências internas ao próprio organismo.

Nesse sentido, poderíamos medir a peculiaridade do vitalismo de Canguilhem. Mais do que o conjunto de funções que resiste à morte, a vida em Canguilhem é o processo que se serve continuamente de dinâmicas de polaridade interna com a morte e as crises provocadas pela doença, para produzir sistemas em perpétua dialética de desequilíbrio e equilíbrio. Se o "verdadeiro projeto biológico" só pode ser o retorno ao equilíbrio, sendo que "todo o resto, ou seja, a organização, o crescimento, o desenvolvimento, o aprendizado e a reprodução invariante não são da ordem do projeto, mas perturbações aleatórias que felizmente o contrariam" (Atlan, 1992, p. 284), então a biopolítica que podemos derivar de Canguilhem será necessariamente política que visa garantir as condições para a experiência dessa paradoxal processualidade do vivente: uma biopolítica da mobilidade normativa. No entanto, essa biopolítica será, paradoxalmente, algo como uma tanatopolítica. "Tanatopolítica”, não porque se trata de uma política que se funda na gestão calculista da morte e de suas figuras, ou seja, nesta compreensão de que "a vida se defende e se desenvolve apenas através da ampliação progressiva do círculo da morte" (Esposito, 2008, p. 110). ${ }^{17}$ "Tanatopolítica”, porque se trata de uma política que quer, com a força pulsional dos movimentos que dissolvem nossas fixações a configurações normativas determinadas, livrar-se das barreiras antropológicas impostas pela fixação compulsiva à configuração atual do homem, com seu tempo, seu espaço e suas normas, porque compreender a função dinâmica da morte e da doença talvez seja o primeiro passo decisivo para criar outra vida.

\section{A vidA TEM SUA MANEIRA DE RESOLVER PROBLEMAS ONTOLÓGICOS ${ }^{18}$}

Mas se quisermos compreender de forma mais precisa tal biopolítica como mobilidade normativa fundada na processualidade da atividade vital, devemos voltar nossos olhos à maneira pela qual ela reconfigura a experiência da contingência. Essa experiência pode fornecer-nos uma via importante para o potencial de crítica do capitalismo presente na biopolítica vitalista.

bordas, que tudo o que foi bom e grande na humanidade entra e sai por ela, em pessoas prontas a autodestruírem-se, e é preferível a morte à saúde que nos propõem".

17 Esposito usa o termo para descrever a peculiaridade da relação entre política e biologia no nazismo. Política no interior da qual a administração médica da vida é indissociável da extensão do circuito das vidas a serem eliminadas. 18 Muitas das discussões que se seguem sobre a contingência não seriam para mim pensáveis sem ter-me deixado anteriormente tocar pelas elaborações de Larissa Agostinho a respeito da contingência em Hegel e em Mallarmé (cf. Agostinho, 2014). 


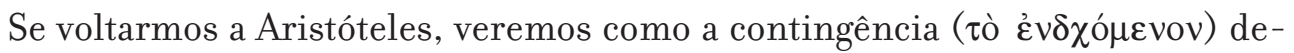
signa tanto o que poderia não ser quanto o que poderia ser de outra forma, ou seja, tanto coisas que podem não ser quanto atributos que podem ou não pertencer a uma coisa. ${ }^{20}$ Temos aqui duas figuras complementares da possibilidade de existência do que não é necessário, isso se aceitarmos a definição clássica do necessário como "aquilo em virtude do qual é impossível que um coisa seja de outra forma” (Aristóteles, 1966a, $1015 \mathrm{~b}$ ). Figuras que serão assumidas pela posteridade como definições praticamente insuperáveis da contingência. É contingente que eu saia hoje para ir ao mercado e encontre, por acaso, meu devedor ou que eu abra um buraco para plantar uma árvore e encontre o dinheiro de sonegação fiscal do Banco Itaú. É contingente que Sócrates tenha predicações acidentais ( $\sigma \cup \mu \beta \varepsilon \beta \eta \kappa o ́ \varsigma)$ como ser branco ou negro. Pois se Sócrates for branco ou negro, estiver sentado ou em pé, nada mudará em sua essência, mesmo que tais atribuições não estejam na mesma distância em relação às determinações essenciais. Não há, para Aristóteles, ontologia do acidente. Mas, principalmente, por não se confundirem com a essência de Sócrates, tais determinações acidentais são intercambiáveis; do ponto de vista ontológico seus opostos se equivalem. Logo, levando em conta a perspectiva de uma compreensão substancial da essência, tais predicados são intercambiáveis. Da mesma forma, a existência ou não do que tem o estatuto de contingência é, do ponto de vista ontológico, indiferente e intercambiável. Não há ontologia do contingente.

Essa liberalidade aristotélica em relação à existência do que não pode ser visto como produzido por uma causa determinada (cf. Aristóteles, 1966b, 196a, 196b) nem assegurado pela necessidade ontológica, coloca-nos, no entanto, diante de uma compreensão da contingência bem definida por Hegel: "essa unidade da possibilidade e da efetividade (Wirklichkeit) é a contingência (Zufälligkeit). O contingente é um efetivo que, ao mesmo tempo, é determinado apenas como possibilidade, cujo outro ou oposto também é" (Hegel, 1986, p. 230). A contingência é a unidade da possibilidade e da efetividade porque, embora existente, ela conserva a marca do que poderia não ser, do que é mera possibilidade. O outro de si, sua inexistência, seu oposto, era igualmente possível. Daí porque ela é, aos olhos de Hegel, o espaço de uma contradição maior. "O contingente não tem fundamento, porque é contingente e, da mesma forma, tem um fundamento, porque, enquanto contingente, é". Sua existência não tem fundamento por estar corroída pela situação de mero possível, ela é vizinha do não ser, como dizia Aristóteles, mas ao mesmo tempo tem alguma forma de fundamento por participar da efetividade posta. Assumir a existência efetiva da contingência é, para Hegel,

20 Aubenque, lembrando como Aristóteles designa o contingente tanto como o que pode ser de outra forma como o que pode não ser, dirá acertadamente: "todos os poder-ser-de-outra-forma supõem como seu fundamento o poder-não-ser” (Aubenque, 2013, p. 326). 
Uma gerta latitude: Georges Canguilhem, biopolítica e vida como errância

confrontar-se com o que é uma "interversão posta imediata" (gesetzte unvermittelte Umschlagen), ou seja, com uma passagem contínua entre opostos que nunca se estabiliza e que por isso abre a experiência a uma "absoluta inquietude do devir" (absolute Unruhe des Werdens).

Mas notemos um ponto. Tal inquietude é absoluta apenas para uma filosofia, como a hegeliana, que, ao recusar distinções ontológicas estritas entre a contingência e a necessidade, procura compreender como o necessário engendra-se a partir da efetividade, como a efetividade produz a necessidade, produz um "não poder ser de outra forma". O que não significa que a realidade atual deve ser filosófica e completamente justificada, como já se criticou Hegel em mais de uma vez. Antes, significa compreender como os fenômenos contingentes, por não encontrarem lugar na determinação necessária da realidade atual, transfiguram-se em necessidade ao inaugurar processualidades singulares. Por isso, a crítica da necessidade ontologicamente assegurada em relações de causalidade determinada não leva Hegel a reduzir toda existência à condição de existência desconexa. ${ }^{21}$

A reflexão sobre a vida a partir de Canguilhem mostra-nos algo próximo da problemática hegeliana. Primeiramente, ela mostra como o contingente aparece como o impredicável, como o caso fora de lugar no interior da norma. Por isso, ele é aquilo que traz uma experiência de a-normatividade que, para ser real, precisa implicar a possibilidade de desorganização efetiva; possibilidade esta que não é apenas um risco calculado, mas é o que muitas vezes se realiza. A vida joga com seu fim para adiá-lo ao máximo.

Por outro lado, a contingência é exatamente aquilo que não poderia ser outro, pois é o que não pode ser intercambiável. A partir do momento em que ela ocorre, o organismo transforma tal acontecimento em motor para a modificação de seu padrão global de regulação, ele abandona as normas, a vida entra em transbordamento em relação às normas anteriores, reorientando sua história ao explorar possíveis que estavam até então em estado de latência. Lembremos, por exemplo, como um dos processos biológicos fundamentais de criação de novas formas é a simbiose (cf. David-Ménard, 2011, p. 292). Processo que, em vários casos, deve ser compreendido como uma relação contingente de combinação entre unidades biológicas, relação que não respeita as clas-

210 que é o resultado necessário de um empreendimento como o apresentado em Meillassoux (2006). Em seu caso, a supressão da garantia ontológica do princípio de razão leva-nos à contemplação da contingência desconexa e à crença equivocada de que tudo poderia ser outro, ou não ser. Pois Meillassoux parece preso a uma inversão da nostalgia da analiticidade do fundamento. Tudo se passa como se fosse o caso de afirmar que, "se houvesse fundamento, ele fundamentaria a realidade com o selo da necessidade analiticamente assegurada. Mas, como ele não existe, como a ilusão de sua presença se foi, como ficamos sozinhos no mundo, tudo é agora desconexo". E do contingente nada se diz, a não ser o fato de ele ser radicalmente desprovido de sentido e marca de um tempo instantaneísta, como se Malebranche guardasse sua noção de tempo, mas agora sem Deus, para assegurar a criação contínua das coisas estáveis. 
sificações anteriores dos viventes e que produz formas que não são completamente compreensíveis a partir do mero cálculo de funções de adaptação. Através da simbiose, por exemplo, um encontro contingente pode aparecer como mecanismo de transformação.

Por isso, podemos dizer que a contingência leva-nos a uma compreensão mais determinada da processualidade. Por ter propriedades processuais, ela pode colocarse como fundamento para as transformações do organismo ou, se quisermos, ela se coloca como fundamento para um organismo cuja identidade é definida exatamente pela sua capacidade de entrar em errância, pela sua "capacidade transitiva” de não se deixar pensar sob a forma da identidade. Nesse contexto, perde o sentido falar que a contingência é o que poderia ser outro. Na verdade, se há algo que poderia ser outro ele é, ao contrário, o padrão normativo do meio no qual se encontra o organismo, este sim em contínua transitividade.

Poderíamos tentar contra-argumentar explorando a noção de "erro" como engano possível na decodificação das mensagens emitidas entre genes. Lembremos da seguinte passagem de Canguilhem.

Já que as enzimas são os mediadores pelos quais os genes dirigem as sínteses intracelulares de proteínas, já que a informação necessária para essa função de direção e de vigilância está inscrita nas moléculas de ácido desoxirribonucleico no nível do cromossomo, essa informação deve ser transmitida como uma mensagem do núcleo ao citoplasma, onde deve ser interpretada a fim de que seja reproduzida, recopiada, a sequência de ácidos aminados constitutiva da proteína a sintetizar. Mas, não importa qual seja o modo, não existe interpretação que não implique um engano possível. A substituição de um ácido aminado por um outro cria a desordem por ininteligência do comando (Canguilhem, 2002, p. 251).

Ou seja, haveria uma contingência irredutível advinda do erro possível no processo de transmissão de informações e de replicação da mensagem genética no nível celular. Um erro que apenas exporia a fragilidade do organismo em perseverar em seu ser. Dessa modo, os organismos estariam diante de duas formas de contingência: "de uma parte, as aleatoreidades (aléas) ambientais perturbando o mundo da vida e, de outra parte, um acaso (hasard) intrínseco engendrado pelos mecanismos biológicos e ecológicos selecionados durante a evolução" (Pavé, 200\%, p. 8). Ou seja, uma contingência vinculada à relação entre o organismo e o meio, outra relacionada à transmissão de informação genética interna ao organismo. Lembremos ainda que podemos descrever a presença do acaso nos vários níveis de auto-organização dos sistemas vitais: genoma, células, órgão, organismos, populações, comunidades e ecossistema (cf. Pavé, 2007, p. 99). 
Uma certa latitude: Georges Ganguilhem, biopolíticiga e vida como errância

No entanto, o exemplo de Canguilhem a respeito de uma forma de "acaso intrínseco" aos mecanismos do organismo mostra-nos algo a mais. De fato, a possibilidade do erro no nível celular é uma das formas mais fortes de expressão da função do acaso na biologia. Um erro que não tem valor em si, positivo ou negativo, mas poderá adquirir um valor. Se seu valor não for meramente negativo, se o organismo for capaz de ter responsividade, usando sua capacidade de autodestruição desorganizadora e inibindo-a lateralmente, o erro desempenhará essa velha astúcia hegeliana que nos lembra como o caminho do erro se releva como caminho da verdade. Caminho que nos mostrará como "a ocorrência de erros é necessária para a redução do nível de redundância nas organizações biológicas, abrindo espaço para a configuração de novas organizações" (Franco, 2011, p. 96). Através do erro, produzem-se anomalias que poderão ou não, de acordo com o contexto de ocorrência, levar a novas formas de vida. ${ }^{22}$ Vemos, assim, um exemplo de como a contingência pode produzir retroativamente a necessidade.

\section{O GAPITALISMO DESGONHEGE A GONTINGÊNGIA}

Por fim, poderíamos perguntar se tal ideia de desorganização permanente seguida de reorganização não seria um conceito fraco de acaso e contingência, uma espécie bizarra de "contingência controlada" por estruturas de relações. Poderíamos mesmo perguntar se tal ideia não seria apenas um símile da realidade social do capitalismo avançado, marcada pela flexibilização constante e pela desorganização controlada pela processualidade dinâmica do capital. ${ }^{23}$ Pois em que uma biopolítica da mobilidade normativa poderia servir de fundamento para uma crítica do capitalismo em sua fase de flexibilização geral de identidades e processos?

A fim de responder tal pergunta, seria importante lembrar que a desorganização produzida pelo capital é a condição para que um princípio geral de equivalência, encarnado na figura da forma-mercadoria, permaneça como uma espécie de axioma intocado. As características fundamentais do mundo flexível do capital são a intercambialidade e a reversibilidade. Circulação de intercâmbio e reversão que só podem operar por serem movimentos de uma estrutura marcada pela univocidade, mesmo se tal univocidade se pluralize em múltiplas formas. Trata-se da univocidade do capital.

22 Nesse sentido, "dizemos que tais alterações são acidentais, que elas ocorreram por acaso. E como elas constituem a única fonte possível de modificações do texto genético, único depositário das estruturas hereditárias do organismo, segue-se necessariamente que apenas o acaso é a fonte de toda novidade, de toda criação na biosfera" (Monod, 1970, p. 14, grifo no original).

23 Devo a crítica precisa a uma intervenção de Judith Butler em colóquio no qual apresentei, pela primeira vez, essa ideia, no ano de 2012 em Santiago do Chile. 
Tal univocidade se realiza por impor ao tempo um regime peculiar de esvaziamento. Pois o tempo do capital é a eternidade do eternamente reversível, o tempo das operações feitas sempre com termos intercambiáveis e que, por isso, tem como principal função a comensurabilidade. A diferença entre a flexibilização do capital e a atividade vital não é, assim, um diferença de grau, na qual a primeira seria a versão "controlada" da segunda. Não chegaremos à atividade vital intensificando os processos internos ao capitalismo, mesmo que em sua dinâmica o capitalismo procure, a sua maneira, mimetizar a vida.

De fato, Marx já falava, ao discorrer sobre o fetichismo no livro iı de 0 capital, que a capacidade de autovalorização do capital dava a impressão de estarmos diante de um organismo vivo (cf. Marx, 1988, l. III). Ao aparecer como capital produtor de juros, temos a forma D-D', na qual o valor valoriza a si mesmo através das atividades financeiras, sem passar assim diretamente pela incorporação do dinheiro em mercadoria. Nesse contexto de autovalorização aparentemente "espontânea”, Marx (1988, p. 522) dirá que "o dinheiro é agora um corpo vivo que quer multiplicar-se". Mas essa característica de quase "geração espontânea" da mais-valia através da autovalorização do capital nunca poderia se passar pela atividade vital.

Na verdade, a diferença entre a dinâmica do capital e a atividade vital é qualitativa. A atividade vital não conhece a intercambialidade e a reversibilidade, mesmo que ela conheça as repetições. Como foi dito, contrariamente ao que alguns acreditam, um acontecimento contingente não é aquilo que poderia ter sido outro ou que simplesmente poderia não ter sido. Poder ser outro é poder ser trocado pelo outro, da mesma forma como poder não ter sido é poder ser trocado pelo oposto da existência, a saber, o não ser. Nos dois casos, há uma estrutura de intercambialidade servindo de pressuposto ao conceito de contingente. Contingente é, nessa perspectiva, o que é intercambiável sem prejuízo para a estabilidade nocional de uma substância que me aparece como previamente assegurada em sua identidade formal; por isso, além de intercambiável, o contingente nessa perspectiva é marcado pela reversibilidade. Nada mais distante disso do que a perspectiva canguilhemeana (e hegeliana) aqui apresentada, toda ela construída a partir da aproximação entre a contingência e o acontecimento. Essa perspectiva leva-nos a reconfigurar a noção de necessidade a partir da reflexão sobre os modelos de constituição de relações necessárias a partir de processualidades retroativas.

Nesse sentido, é possível dizer que um acontecimento contingente é exatamente aquele que traz o impercebível e o incomensurável à cena. Incomensurável não por ser infinitamente grande ou pequeno, mas por ser infinitamente outro. Por isso, ele quebra a redundância de um sistema de informações que sempre precisa encontrar, entre os fatos dispersos, um denominador comum de contagem. Tal outra cena produzida 
Uma certa latitude: Georges Ganguilhem, biopolíticiga e vida como errância

pelo reconhecimento da contingência é o que nos leva à essa auto-organização paradoxal na qual os sistemas vitais estão em contínua reordenação, instituindo novas normatividades que podem mudar radicalmente o modelo de regulação do sistema, afirmando sua capacidade transitiva. Essa outra cena, será o caso sempre de lembrar, insiste radicalmente fora do tempo do capital. Pois - e por que não dizer as coisas por completo? - é a vida em sua soberania insubmissa que nos puxa para fora desse tempo.A

Agradecimentos. Este artigo foi escrito a partir de um estágio de fellow no Stellenboch Institute of Advanced Studies (STIAS - África do Sul), no interior do projeto "Por uma patoanálise da existência” composto por mim e pelos professores Philippe Van Haute, Ariane Bazan, Herman Westernick e Desmond Painter. A todos eles, meus agradecimentos.

\author{
Vladimir SAFATLE \\ Departamento de Filosofia, \\ Faculdade de Filosofia, Letras e Ciências Humanas, \\ Universidade de São Paulo, Brasil. \\ vsafatle@yahoo.com \\ A certain latitude: \\ Georges Canguilhem, bio-politics and life errancy
}

\begin{abstract}
This article aims to discuss the possibility of a bio-political approach that wouldn't be just the description of disciplinary mechanisms of bodies' administration and the calculating administration of life, but that could provide the ground for a social criticism of contemporary capitalism. This bio-political approach is derived from Georges Canguilhem's vitalism with its discussions about vital normativity, the relationship between normal and pathological and the characteristic errancy of vital activity. At the end, we will see how the inner process of the concept of life could appear as a major strategy for the reorientation of critical thought and a theory on the concept of norms.
\end{abstract}

KEYwords • Bio-politics. Errancy, Life. Normativity. Pathology. Normality. Contingence.

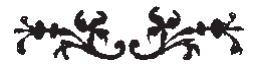




\section{REFERÊNGIAS BIBLIOGRÁFICAS}

Agamben, G. Homo sacer; o poder soberano e a vida nua. Belo Horizonte: Editora da UFMG, 2002.

Agostinho, L. Les plies et déplies du hasard à la recherche de l'infini. Paris, 2014. Thése de doctorat d'État.

(Philosophie). Université de Paris iv.

Ameisen, J. C. La sculpture du vivant: le suicide cellulaire et la mort créatrice. Paris: Seuil, 2003.

American Psychiatric Association. Diagnostic and statistical manual of mental disorders. Washington: APA, 2013. (APA)

Aristóteles. Métaphysique. Paris: Belle Lettres, 1966a. . Physique. Paris: Belle Lettres, 1966b.

Atran, H. Entre le cristal et la fumée: essai sur l'organisation du vivant. Paris: Seuil, 1979. . L'organisation biologique et la théorie de l'information. Paris: Hermann, 1992.

Aubenque, P. Le problème de l'être chez Aristote: essai sur la problématique aristotélicienne. Paris: PUF, 2013.

Badiou, A. L'aventure de la philosophie française. Paris: La Fabrique, 2012.

Bataille, G. A parte maldita, precedida de A noção de dispêndio. Belo Horizonte: Autêntica, 2013.

Bergson, H. L'évolution créatrice. Paris: PUF, 2007.

Brandom, R. Animating ideas. Harvard: Harvard University Press, 2009.

Canguilhem, G. Etudes d'histoire et philosophie des sciences. Paris: Vrin, 1983. . La santé: concept vulgaire et question philosophique. Toulouse: Sables, 1990 .

. Vie. In: Aavv. Dictionnaire de la philosophie. Paris: Enciclopaedia Universalis/Albin Michel, 199ob.

p. $1150-78$. . Escritos sobre a medicina. Rio de Janeiro: Forense, 2000.

. O normal e o patológico. Rio de Janeiro: Forense Universitária, 2002.

. La connaissance de la vie. Paris: Vrin, 2003.

Idéologie et rationalité dans l'histoire des sciences de la vie. Paris: Vrin, 2009.

DALED, P. Santé, folie et vérité aux xixème et xxème siècles: Nietzsche, Canguilhem et Foucault. In:

(Org.). L'envers de la raison: amlentour de Canguilhem. Paris: Vrin, 2008. p. 115-4, 0. (Org.). L'envers de la raison: amlentour de Canguilhem. Paris: Vrin, 2008.

Dagonet, F. Georges Canguilhem: philosophie de la vie. Paris: Les Empêcheurs de Penser en Rond, 1997.

David-MÉnard, M. Éloge de l'hasard dans la vie sexuelle. Paris: Hermann, 2011.

Debru, G. Georges Canguilhem, science et non-science. Paris: Presses de l'Ecole Normale Supérieure, 2004.

Deleuze, G. Logique du sens. Paris: Seuil, 1969. Pourparleurs. Paris: Minuit, 1990.

Durkheim, E. Les règles de la méthode sociologique. Paris: Flammarion, 1988. Le suicide. Paris: PUF, 2000.

ÉLUARD, P. Oeuvres complètes. Paris: Galimard, 1946. v. 2.

Esposito, R. Bios: biopolitics and philosophy. Minneapolis: University of Minnesota Press, 2008.

Fichant, M. Georges Canguilhem: philosophe, historien des sciences. Paris: PUF, 1993.

Foucault, M. Les mots et les choses. Paris: Gallimard, 1966.

Histoire de la séxualité. Paris: Gallimard, 1976. v. 1.

Sécurité, territoire, population. Paris: Seuil, 2004.

Franco, F. A natureza das normas: o vital e o social na filosofia de Georges Canguilhem. São Paulo, 2011. Dissertação (Mestrado em Filosofia). Departamento de Filosofia da Universidade de São Paulo.

Giroux, E. Après Canguilhem: définir la santé et la maladie. Paris: PUF, 2010.

Goldstein, K. La structure de l'organisme. Paris: Gallimard, 1983.

HeGged, G. W. F. Wissenschaft der Logik II. Frankfurt: Suhrkamp, 1986.

Новвеs, T. Leviatã. São Paulo: Martins Fontes, 2002. 
Uma gerta latitude: Georges Canguilhem, biopolítica e vida como errância

ЈАсов, F. La logique du vivant: une historie de l'hérédité. Paris: Gallimard, 1970.

KJellén, R. Grundriss zu einem System der Politik. Leipzig: Rudolf Leipzig Hirtel, 1920.

Le Blanc, G. Canguilhem et les normes. Paris: PUF, 1998.

Macherey, P. De Canguilhem à Foucault: la force des normes. Paris: La Fabrique, 2010.

Marx, K. 0 capital. Rio de Janeiro: Civilização Brasileira, 1988. Livro III, v. 5.

Meillassoux, Q. Aprés da finitude: essai sur la nécessité de la contingence. Paris: Seuil, 2006.

Monod, J. Le hasard et la nécessité: essai sur la philosophie naturelle de la biologie moderne. Paris: Seuil, 1970.

Munle, M. Eine Genealogie der Biopolitik: zum Begriff des Lebens bei Foucault und Canguilhem. Bielefeld:

Transcript, 2008.

Nietzsche, F. Crepúsculo dos deuses. São Paulo: Companhia das Letras, 2002.

PAvÉ, A. La nécessité du hasard: vers une théorie synthétique de la biodiversité. Les Ulis: EDP Sciences, 2007.

RoBerton, M. Bio-politics: an essay in the physiology, pathology and politics of the social and somatic organism. London: Dent, 1938.

Uexküll, J. Staatsbiologie: Anatomie, Phisiologie, Pathologie des Staates: Berlin: Gedrüber Paetel, 1920. 